\title{
Radical Title of the Crown and Aboriginal Title: North America 1763, New South Wales 1788, and New Zealand 1840
}

DAVID V. WILLIAMS

\begin{abstract}
'Radical title', the underlying or ultimate title of the Crown to all lands within Commonwealth realms, is said to be a feature of English Common law, derived from Anglo-Norman feudal doctrines, that was transplanted to most British colonies. The focus of this chapter is the history of this doctrine and how that impacted on the recognition or otherwise of the sovereignty, laws, titles and rights of indigenous peoples. Canada, Australia and New Zealand are three modern nation states (the former two having federal constitutions) that emerged from a number of colonies in the British Empire. In all of these colonies, from a very early point in colonial rule, European settlers came to dominate all aspects of political, social, cultural and economic life. In the laws of the colonies, indigenous peoples - variously known as Natives, Indians, Eskimos, Aborigines, Maori (and sometimes as savages, primitive barbarians and a range of other racist descriptions) - were explicitly marginalised by legal dispensations put in place. They were subject to a range of policies labelled as amalgamation, assimilation, adaptation or integration, with a view to 'civilising' those who did not perish during the drastic population decline that followed the arrival of European settlers.

When almost all the colonies, protectorates, protected states and other polities within that Empire became independent states in the United Nations during the decolonisation era after World War II, ${ }^{1}$ the colonised peoples of British North America within what is now Canada, of New Holland in what is now known as Australia, and of New Zealand found themselves a small minority within constitutional monarchies and an electoral system based on a democratic franchise of one person, one vote.
\end{abstract}

${ }^{1}$ K. Roberts-Wray, Commonwealth and Colonial Law (London, 1966). 
During the latter part of the twentieth century, however, an increasingly vocal and persistent number of movements and protest actions by indigenous peoples, with support from elements of civil society in the majority population, forced state institutions to search for ways and means to attend to their calls for justice and redress. One of the responses in each of the three legal systems was the development by the judicial branch of government of a doctrine usually known as aboriginal title. ${ }^{2}$ In the enunciation of this doctrine by judges and scholars, a good deal of attention has been devoted to the notion of the radical title of the Crown to all lands.

A reasonably coherent account of legal history on this topic might seem possible, and even plausible, if one focused on the development of the Common law in just one of the three legal systems. The value of comparative analysis and historical contextualisation in this instance is that the semblance of coherence and clarity tends to evaporate when one investigates judicial pronouncements on this Anglo-Norman doctrine as a substratum element of aboriginal title rights in the three settlerdominated jurisdictions, and in the advice proffered to the sovereign by the Judicial Committee of the Privy Council in a small number of much cited decisions, including especially two appeals from African territories. This essay notes, in particular, the divergent judicial responses to the status and relevance of pre-colonial indigenous norms and values when evaluating aboriginal title claims. These range from outright rejection of their relevance based on 'waste lands' or terra nullius conceptions, to limited acceptance of usufructuary and possessory rights, to a broader acceptance more recently that aboriginal title must be understood in the light of prior and present indigenous understandings.

I begin with quotations from relatively recent appellate court judgments in each of the three jurisdictions. The first is from the decision of a full bench of the New Zealand Court of Appeal in litigation asserting Maori customary rights over foreshore and seabed lands in the Marlborough Sounds. ${ }^{3}$ In her leading judgment Elias CJ wrote:

[30] The radical title of the Crown is a technical and notional concept. It is not inconsistent with common law recognition of native property, as $R v$ Symonds, Manu Kapua v Para Haimona and Nireaha Tamaki v Baker

2 P. G. McHugh, Aboriginal Title: The Modern Jurisprudence of Tribal Land Rights (Oxford, 2011); K. McNeil, Common Law Aboriginal Title (Oxford, 1989).

3 Attorney-General v. Ngati Apa [2003] 3 NZLR 643 (henceforth, Ngati Apa). 
make clear. Brennan J described such radical title in Mabo $v$ Queensland (No 2) (1992) 175 CLR 1 at p 50 as:

'... merely a logical postulate required to support the doctrine of tenure (when the Crown has exercised its sovereign power to grant an interest in land) and to support the plenary title of the Crown (when the Crown has exercised its sovereign power to appropriate to itself ownership of parcels of land within the Crown's territory).'

[31] Any property interest of the Crown in land over which it acquired sovereignty therefore depends on any pre-existing customary interest and its nature, as the Privy Council in Amodu Tijani v Secretary, Southern Nigeria held. The content of such customary interest is a question of fact discoverable, if necessary, by evidence (Nireaha Tamaki $v$ Baker at p 577). As a matter of custom the burden on the Crown's radical title might be limited to use or occupation rights held as a matter of custom (as appears to be the position described in St Catherine's Milling and Lumber Co $v$ The Queen and as the tribunal in William Webster's Claim seems to have thought might be the extent of Maori customary property). On the other hand, the customary rights might 'be so complete as to reduce any radical right in the Sovereign to one which only extends to comparatively limited rights of administrative interference' (Amodu Tijani v Secretary, Southern Nigeria at $\mathrm{p}$ 410). The Supreme Court of Canada has had occasion recently to consider the content of customary property interests in that country. It has recognised that, according to the custom on which such rights are based, they may extend from usufructory [sic] rights to exclusive ownership with incidents equivalent to those recognised by fee simple title (see, for example, Delgamuukw v British Columbia [1997] 3 SCR 1010 at paras $110-119$ per Lamer CJ). ${ }^{4}$

In 2014, many decades of expensive litigation by large numbers of indigenous plaintiffs on aboriginal title issues, going back to $1983,{ }^{5}$ finally culminated in the first declaration of aboriginal title by the Supreme Court of Canada in respect of land that had never been ceded nor been the subject of a historic treaty with the Crown. The declaration in favour of the Tsilhqot'in Nation covered a 1,900 square kilometre area of British Columbia. In her judgment for the entire court McLachlin CJ made these observations on radical title:

[69] The starting point in characterizing the legal nature of Aboriginal title is Dickson J.'s concurring judgment in Guerin, discussed earlier. At the time of assertion of European sovereignty, the Crown acquired radical

${ }^{4}$ Ibid., 655-6.

${ }^{5}$ Calder v. Attorney-General of British Columbia [1973] SCR 313 (henceforth, Calder). See H. Foster, H. Raven, and J. Webber (eds.), Let Right Be Done: Aboriginal Title, the Calder Case, and the Future of Indigenous Rights (Vancouver, 2007). 
or underlying title to all the land in the province. This Crown title, however, was burdened by the pre-existing legal rights of Aboriginal people who occupied and used the land prior to European arrival. The doctrine of terra nullius (that no one owned the land prior to European assertion of sovereignty) never applied in Canada, as confirmed by the Royal Proclamation of 1763 . The Aboriginal interest in land that burdens the Crown's underlying title is an independent legal interest, which gives rise to a fiduciary duty on the part of the Crown.

[70] The content of the Crown's underlying title is what is left when Aboriginal title is subtracted from it: s. 109 of the Constitution Act, 1867; Delgamuukw. As we have seen, Delgamuukw establishes that Aboriginal title gives 'the right to exclusive use and occupation of the land ... for a variety of purposes', not confined to traditional or 'distinctive' uses (para. 117). In other words, Aboriginal title is a beneficial interest in the land: Guerin, at p. 382. In simple terms, the title holders have the right to the benefits associated with the land - to use it, enjoy it and profit from its economic development. As such, the Crown does not retain a beneficial interest in Aboriginal title land.

[71] What remains, then, of the Crown's radical or underlying title to lands held under Aboriginal title? The authorities suggest two related elements - a fiduciary duty owed by the Crown to Aboriginal people when dealing with Aboriginal lands, and the right to encroach on Aboriginal title if the government can justify this in the broader public interest under s. 35 of the Constitution Act, 1982. The Court in Delgamuukw referred to this as a process of reconciling Aboriginal interests with the broader public interests under s. 35 of the Constitution Act, $1982 .^{6}$

This signal victory for the Tsilhqot'in Nation still leaves a good deal of scope for ambiguity or ambivalence about the nature of radical title. As Ryan Beaton has written, Canadian judicial doctrine 'has long been torn between a nation-with-nation vision and a vision of perfected Crown sovereignty'. If recognition of prior occupation and pre-existing systems of indigenous law truly are burdens on underlying Crown title, then how is it that the Crown, unilaterally it seems, may invoke 'the right to encroach on Aboriginal title if the government can justify this in the broader public interest' as stated by the Chief Justice? ${ }^{7}$

${ }^{6}$ Tsilhqot'in Nation v. British Columbia [2014] 2 SCR 257 (henceforth, Tsilhqot'in), at 292-3.

7 R. Beaton, The Crown Fiduciary Duty at the Supreme Court of Canada: Reaching Across Nations, or Held Within the Grip of the Crown? (Waterloo, 2018), 14. See also J. Borrows, 'The Durability of terra nullius: Tsilhqot'in Nation v British Columbia', University of British Columbia Law Review, 48(3) (2015), 701-42. 
The doctrine of radical title also played a large part in the reasoning of judges of the High Court of Australia when prior decisions declaring that aboriginal title was not part of Australian Common law were overruled. The most frequently cited statement is from the judgment of Brennan J (with which Mason CJ and McHugh J agreed):

51. By attributing to the Crown a radical title to all land within a territory over which the Crown has assumed sovereignty, the common law enabled the Crown, in exercise of its sovereign power, to grant an interest in land to be held of the Crown or to acquire land for the Crown's demesne. The notion of radical title enabled the Crown to become Paramount Lord of all who hold a tenure granted by the Crown and to become absolute beneficial owner of unalienated land required for the Crown's purposes. But it is not a corollary of the Crown's acquisition of a radical title to land in an occupied territory that the Crown acquired absolute beneficial ownership of that land to the exclusion of the indigenous inhabitants. If the land were desert and uninhabited, truly a terra nullius, the Crown would take an absolute beneficial title (an allodial title) to the land for the reason given by Stephen C.J. in Attorney-General v. Brown (1847) 1 Legge, at pp 317-318: there would be no other proprietor. But if the land were occupied by the indigenous inhabitants and their rights and interests in the land are recognized by the common law, the radical title which is acquired with the acquisition of sovereignty cannot itself be taken to confer an absolute beneficial title to the occupied land. Nor is it necessary to the structure of our legal system to refuse recognition to the rights and interests in land of the indigenous inhabitants. The doctrine of tenure applies to every Crown grant of an interest in land, but not to rights and interests which do not owe their existence to a Crown grant. The English legal system accommodated the recognition of rights and interests derived from occupation of land in a territory over which sovereignty was acquired by conquest without the necessity of a Crown grant.

52. [...] In Amodu Tijani, the Privy Council admitted the possibility of recognition not only of usufructuary rights but also of interests in land vested not in an individual or a number of identified individuals but in a community. Viscount Haldane observed (1921) 2 AC, at pp 403-404:

The title, such as it is, may not be that of the individual, as in this country it nearly always is in some form, but may be that of a community. Such a community may have the possessory title to the common enjoyment of a usufruct, with customs under which its individual members are admitted to enjoyment, and even to a right of transmitting the individual enjoyment as members by assignment inter vivos or by succession. To ascertain how far this latter development of right has progressed involves the study of the history of the particular community and its usages in each case. Abstract principles fashioned a priori are of but little assistance, and are as often as not misleading. 
Recognition of the radical title of the Crown is quite consistent with recognition of native title to land, for the radical title, without more, is merely a logical postulate required to support the doctrine of tenure (when the Crown has exercised its sovereign power to grant an interest in land) and to support the plenary title of the Crown (when the Crown has exercised its sovereign power to appropriate to itself ownership of parcels of land within the Crown's territory). Unless the sovereign power is exercised in one or other of those ways, there is no reason why land within the Crown's territory should not continue to be subject to native title. It is only the fallacy of equating sovereignty and beneficial ownership of land that gives rise to the notion that native title is extinguished by the acquisition of sovereignty. ${ }^{8}$

One might conclude from reading the above quotations that the radical title of the Crown and the feudal doctrine of tenures have happily accommodated recognition of indigenous peoples' aboriginal title rights in all three Commonwealth realms. There might be some variance as between recognition of usufructuary and possessory rights only, or a fuller recognition of native title rights, but those rights are not only cognisable but also justiciable and enforceable in ordinary courts. Nevertheless, it was not always thus, and comparative legal history tells a more complicated tale.

The starting point, indeed, is not legal history at all, but legal fiction. Brendan Edgeworth correctly observed that the radical title of the Crown and feudal tenure systems did not appear overnight following the Norman Conquest in 1066 and the replacement of English landholders with Norman feudal lords. Some centuries elapsed before 'the role of the Crown in the ownership of land came to be reconceived in much more expansive terms. Not only did leading feudal overlords owe their titles to grants from the monarch, but all landowners, including tenants lower down the pyramid, were now presumed to have received their titles from grants subsequent upon those original grants', though 'this pattern of creation of titles never occurred as historical fact'. ${ }^{9}$ Edgeworth notes that while English legal historians have no doubt that "this "wholly mythic", doctrinal revisionism took place', they do not pinpoint with precision

${ }^{8}$ Mabo v. Queensland (No 2) [1992] HCA 23 (henceforth, Mabo (No. 2)) (footnotes omitted).

9 B. Edgeworth, 'The Mabo "Vibe" and Its Many Resonances in Australian Property Law', in S. Brennan, M. Davis, B. Edgeworth and L. Terrill (eds.), Native Title from Mabo to Akiba: A Vehicle for Change and Empowerment? (Sydney, 2015), 75-98, at 78. 
when this modern dogma emerged. ${ }^{10}$ Edgeworth also points to Brennan J's Mabo (No. 2) judgment in crediting William Blackstone's Commentaries as the first attempt to try to understand this 'modern' fiction. ${ }^{11}$ Blackstone, despite his Tory connections, was not one who would want to emphasise the Norman yoke in eighteenth-century England. In that era of Whig hegemony Sir Edward Coke's equally fictitious 'ancient constitution', based on documents falsely attributed to the saintly Anglo-Saxon King Edward, still held sway as being basic to English liberties. ${ }^{12}$ Blackstone made clear his adherence to the supposedly ancient constitution when describing the radical title of the Crown. For him,

it became a fundamental maxim and necessary principle (though in reality a mere fiction) of our English tenures, 'that the king is the universal lord and original proprietor of all lands in his kingdom; and that no man doth or can possess any part of it, but what was mediately or immediately been derived as a gift from him to be held upon feodal services. ${ }^{13}$

Invented fiction may be all well and good to account for the evolution of English land law on radical title and on tenures during a number of centuries of feudalism in the medieval period. The magisterial contributions of J. G. A. Pocock have identified some twists and turns as Tudor forms of late feudalism transitioned into the Common law patterns of reasoning that have prevailed since the seventeenth century. ${ }^{14}$ But a feudal form of political economy as such was not part of the baggage transported when England, and later the United Kingdom, began to assert sovereignty over plantations and colonies in overseas continents and islands where there were long established indigenous populations . Mercantilist capitalism, not feudalism, prevailed in the early years of imperial expansion. Laissez-faire capitalism had taken centre stage by

${ }^{10}$ Ibid., 79, citing W. Holdsworth, A History of English Law, vol. II, 4th edn (London, 1936), 200-1, and A. W. B. Simpson, A History of the Land Law, 2nd edn (Oxford, 1986), 47.

11 Edgeworth, 'The Mabo "Vibe", 79 citing the judgment of Brennan J in Mabo (No. 2), at 16 .

12 J. Greenberg, The Radical Face of the Ancient Constitution: St Edward's 'Laws' in Early Modern Political Thought (Cambridge, 2001).

13 W. Blackstone, Commentaries on the Laws of England, Book II: Of the Rights of Things (Oxford, 1766), 51, as quoted in S. Stern's edition, part of The Oxford Edition of Blackstone, ed. W. Prest (Oxford, 2016), 33.

14 J. G. A. Pocock, The Ancient Constitution and the Feudal Law: A Study of English Historical Thought in the Seventeenth Century. A Reissue with a Retrospect (Cambridge, 1987). 
the time cartographers tinted a quarter of the world's map in British imperial pink. Triumphalist rhetoric waxed lyrical about the extent and strength of this empire: 'On her dominions the sun never sets; before his evening rays leave the spires of Quebec, his morning beams have shone three hours on Port Jackson, and while sinking from the waters of Lake Superior, his eye opens upon the Mouth of the Ganges. ${ }^{15}$ Yet, as Maya Jasanoff observed, 'the imperial map was little more than a rose-tinted fiction. It lied time and again. The uniform coloring falsely implied similarities across radically different kinds of domains. ${ }^{16}$ Further to that insight, in this chapter it will be argued that, even as between somewhat similar European settler domains, the doctrine of tenures evolved in radically different ways when judges were called on to assess what (if any) rights or title to land might have been retained by the indigenes after proclamations of British sovereignty.

The application by colonial judges and Privy Counsellors of another passage from Blackstone is an especially important context for understanding the diverging pathways in Australia, Canada and New Zealand. In Commentaries, Book I, Blackstone opined:

[O]ur more distant plantations in America, and elsewhere, are also in some respects subject to the English laws. Plantations, or colonies in distant countries, are either such where the lands are claimed by right of occupancy only, by finding them desart and uncultivated, and peopling them from the mother country; or where, when already cultivated, they have been either gained by conquest, or ceded to us by treaties. And both these rights are founded upon the law of nature, or at least upon that of nations. But there is a difference between these two species of colonies, with respect to the laws by which they are bound. For it is held, that if an uninhabited country be discovered and planted by English subjects, all the English laws are immediately there in force. For as the law is the birthright of every subject, so wherever they go they carry their laws with them. But in conquered or ceded countries, that have already laws of their own, the king may indeed alter and change those laws; but, till he does actually change them, the antient laws of the country remain, unless such as are against the law of God, as in the case of an infidel country.

Our American plantations are principally of this latter sort, being obtained by right of conquest and driving out the natives (with what

15 The British Newspaper Archive, 'The British Empire', Caledonian Mercury, 15 October $1821,4$.

${ }^{16}$ M. Jasanoff, 'Hearts of Darkness: The Incoherence of the British Empire', The New Republic, 244(9) (2013), 48-53, at 49, a review of John Darwin, Unfinished Empire: The Global Expansion of Britain (New York, 2012). 
natural justice I shall not at present enquire) or by treaties. And therefore the common law of England, as such, has no allowance or authority there; they being no part of the mother country, but distinct (though dependent) dominions. They are subject however to the control of the parliament. ${ }^{17}$

Unsurprisingly, none of the judgments quoted above and delivered in Mabo (No. 2) in 1992, Ngati Apa in 2003 and Tsilhqot'in in 2014 embraced Blackstone's notion that a territory might be lawfully occupied by British settlers if they found it desert and uncultivated so that it could be deemed to be 'an uninhabited country' in which all English laws, including of course the radical title of the Crown to all land, were immediately there in force. Quite rightly, from the retrospective comfort of contemporary points of view, judges in those cases have rejected the racism and enthnocentrism undergirding European imperialist thinking in the past that justified the acquisition of territories without even the pretence of obtaining consent from those upon whom colonial rule was imposed. It was not so, however, for many of their judicial forebears.

In considering Blackstone's formulae, it is not at all surprising that inconsistent policies were adopted by decision-makers at the point when British sovereignty was proclaimed, and later by judges scrutinising the basis for those assertions of sovereignty. Did English law (including radical title) automatically apply in new colonies as the birthright of British subjects - regardless, incidentally, of whether they hailed from England, Wales, Scotland, Ireland or other jurisdictions within the United Kingdom? Were the plantations of North America, and the later colonies in Australia and New Zealand, properly claimed by occupancy, by conquest or by treaty? That is not a question for which clear answers are available even to this day. When Blackstone wrote of an 'uninhabited country', did that mean a stretch of territory totally devoid of any human persons? Or rather, was the focus of British policy-makers' attention on whether the inhabitants whom British sailors had 'discovered' were capable of owning property - for which the test would be Lockean notions of cultivation and labour as the basis for private property rights, and without regard to indigenous conceptions of connections to land and country?

17 W. Blackstone, Commentaries on the Laws of England, Book I: Of the Rights of Persons (Oxford, 1765), 104-5, as given in D. Lemming's edition, part of The Oxford Edition of Blackstone, ed. Prest, 75-6. 
Of the three jurisdictions considered in this essay, the Canadian portion of British North America has the most complicated history of intrusions into indigenous territories by Europeans who claimed to have 'discovered' them. There, various indigenous nations controlled military forces, some of whom were allies (and some enemies) of Great Britain in wars against France and later against rebels in the thirteen colonies that became the United States of America. These nations engaged in trade for some centuries with both British and French interests and concluded a great variety of treaty and wampum covenant transactions with Europeans. Beyond the eastern seaboard, there were prairies and mountains where the Hudson Bay Company traded for a long time before gold seekers and settler migrants arrived in the nineteenth century to disperse and displace indigenous populations. Brian Slattery has identified the complexities of the legal instruments by which New France was incorporated into British North America following the Treaty of Paris in $1763 .{ }^{18}$ For Paul McHugh the outcome by the nineteenth century was clear. The status of indigenous peoples had been 'moved from ally to subjects of the Crown'. ${ }^{19}$ By the 1820 s, 'their forms of political organization and representation were denied juridical standing before the courts of Upper Canada. Their relations with the Crown were rendered "political" in the sense of being non-justiciable or unrecognizable in the colonial courts except through the protective agency of the Governor. ${ }^{20}$ When considering the radical title of the Crown and any aboriginal titles or rights that may have survived treaties, conquests and occupation policies, the complexities and the different histories in what are now the provinces of federal Canada were usually disregarded in favour of a primary focus on the Royal Proclamation $1763 .^{21}$ That was certainly the reasoning in the leading case from Canada that was appealed to the Privy Council in 1888:

18 B. Slattery, 'Aboriginal Title and the Royal Proclamation of 1763: Origins and Illusions', working draft paper, 6 December 2019, available at www.researchgate.net/publication/ 337821333, 72-90. See also B. Slattery, 'Paper Empires: The Legal Dimensions of French and English Ventures in North America', in J. McLaren, A. R. Buck and N. E. Wright (eds.), Despotic Dominion: Property Rights in British Settler Societies (Vancouver, 2005), 50-78. But see also E. Cavanagh, 'Possession and Dispossession in Corporate New France, 1660-1663: Debunking a "Juridical History" and Revisiting Terra Nullius', Law and History Review, 32(1) (2014), 97-125.

19 P. G. McHugh, Aboriginal Societies and the Common Law: A History of Sovereignty, Status, and Self-Determination (Oxford, 2004), 156.

20 Ibid., 156.

${ }^{21}$ Ibid., 87-109. 
St Catherine's Milling and Lumber Co. v. The Queen. ${ }^{22}$ The Proclamation dealt with a number of issues following the British defeat of French forces, subsequent capitulations and a treaty. Relevant to this paper is this recognition of indigenous interests:

And whereas it is just and reasonable and essential to Our Interest and the Security of Our Colonies, that the several Nations or Tribes of Indians, with whom We are connected, and who live under Our Protection, should not be molested or disturbed in the Possession of such Parts of Our Dominions and Territories as, not having been ceded to, or purchased by Us, are reserved to them, or any of them, as their Hunting Grounds. ${ }^{23}$

The Proclamation affirmed and extended the policy of Crown preemption. The Crown held a monopoly right to purchase lands from the Indian nations or tribes and to extinguish native title in the land ceded. Any land occupied by settlers prior to a Crown purchase remained lands reserved to the Indians, and settlers were bidden forthwith to remove themselves from such settlements.

Delivering the advice of the Privy Council in the St Catherine's litigation between the government of Canada and the government of Ontario province (from which the indigenous Salteaux nation, a party to the relevant Treaty No. 3, was entirely excluded), Lord Watson concluded that the Royal Proclamation 1763 was the primary instrument to identify whatever indigenous interests there might have been in the land in dispute between Ontario and Canada. Addressing the character of the interests that 'Indian inhabitants had in the lands surrendered' by a treaty, Lord Watson wrote:

Their possession, such as it was, can only be ascribed to the general provisions made by the royal proclamation in favour of all Indian tribes then living under the sovereignty and protection of the British Crown. It was suggested in the course of the argument for the Dominion, that inasmuch as the proclamation recites that the territories thereby reserved for Indians had never 'been ceded to or purchased by' the Crown, the

22 (1888) 14 App Cas 46, [1888] UKPC 70 (henceforth, St Catherine's) on appeal from St. Catharines [sic] Milling and Lumber Co. v. The Queen (1887) 13 SCR 577 (SCC).

${ }^{23}$ Slattery, 'Aboriginal Title and the Royal Proclamation of 1763', Appendix A, 162. Slattery's appendix most usefully sets out the Proclamation text in British Royal Proclamations Relating to America, Volume 12: Transactions and Collections of the American Antiquarian Society, C. S. Brigham (Worcester, MA, 1911), 212-18, which reproduces the original text of the Proclamation printed by the King's Printer, Mark Baskett, in London in 1763. This text, according to Slattery, is the most authoritative printed version of the Proclamation available. 
entire property of the land remained with them. That inference is, however, at variance with the terms of the instrument, which shew that the tenure of the Indians was a personal and usufructuary right, dependent upon the good will of the Sovereign. ... There was a great deal of learned discussion at the Bar with respect to the precise quality of the Indian right, but their Lordships do not consider it necessary to express any opinion upon the point. It appears to them to be sufficient for the purposes of this case that there has been all along vested in the Crown a substantial and paramount estate, underlying the Indian title, which became a plenum dominium whenever that title was surrendered or otherwise extinguished. $^{24}$

Some Canadian scholars detect in that reasoning support for the modern doctrine of aboriginal title - cognisable and enforceable in the courts that has been developed by Canadian judges since Calder in 1973 leading to Tsilhqot'in in 2014. Disagreeing with McHugh for views that are said to be 'neither good history nor good law', 25 they assert that the postCalder jurisprudence 'reassessment' of St Catherine's does not amount to 'a revision of the law' laid down in that case, but rather that modern case law is 'based on a better understanding of Indigenous societies, their relationship with land, and their cultures, including their legal orders' ${ }^{26}$ St Catherine's is accepted as an important precedent but criticised as a flawed precedent owing to factual findings that were 'riddled with prejudicial assumptions about the Salteaux that must have led the Privy Council to conclude that they were too primitive to have laws of their own or any land rights that had not been conferred on them by the Crown'. ${ }^{27}$

In my reading of Lord Watson's advice to Her Majesty, I would note the finding that Salteaux interests in Treaty 3 lands, as recognised by the 1763 Proclamation, were possessory only, were usufructuary only and were protected (if at all) only by 'the goodwill of the Sovereign' - not by judgments of the sovereign's courts. I have long argued that what is indeed 'good law' for the late twentieth and early twenty-first centuries has emerged from 'revisionist legal history'. Even if judges persistently disavow being revisionists - long a feature of Common law

24 St Catherine's, 54-55.

25 Slattery, 'Aboriginal Title and the Royal Proclamation of 1763', 56.

26 K. McNeil, Flawed Precedent: The St Catherine's Case and Aboriginal Title (Vancouver, 2019), 125. See also K. McNeil, 'The Source, Nature, and Content of the Crown's Underlying Title to Aboriginal lands', The Canadian Bar Review, 96(2) (2018), 273-93.

27 McNeil, Flawed Precedent, 187. 
reasoning - that does not mean legal scholars should disregard the actual historical context of bygone precedents. ${ }^{28}$ Judges in $1888 \mathrm{did}$ indeed conclude that indigenous peoples in Canada were too primitive to have laws of their own - as the notion of 'law' was then understood by those judges. That did not mean that indigenous interests were entirely irrelevant to the colonisers' law. It did mean, however, that in the colonisers' law indigenous interests were not recognised as 'ownership' interests; all land was vested in the Crown as an estate 'underlying the Indian title', and vindication of those interests depended on the 'goodwill' (or otherwise) of the political branches of government, not the judicial branch of government.

There was a rather simpler legal history on the application of radical title in Australia. First named New Holland by Europeans who thought of themselves as 'discoverers', the Commonwealth of Australia now covers a continent that has been inhabited by numerous diverse indigenous peoples for many tens of thousands of years. Was that continent uninhabited, desert and uncultivated in 1788 - when a British penal settlement known as New South Wales was established on the continent's east coast, under a military dispensation that bore but a faint resemblance to ordinary English law? ${ }^{29}$ Or in 1828 - when an imperial statute formally applied 'all Laws and Statutes in force within the realm of England' to the colonies of New South Wales and Van Diemen's Land (now Tasmania) $?^{30}$ The answer of Australian and Privy Council judges prior to 1992 was clear. The continent was indeed 'uninhabited' in law.

The most important pre-Mabo (No. 2) case in Australia on radical title was the 1847 New South Wales Supreme Court decision AttorneyGeneral (NSW) v. Brown. ${ }^{31}$ This was a dispute between the Crown and the lessee of land who mined for coal despite an explicit reservation in the Crown grant that rights to mine gold, silver and coal were retained by the Crown. The defendant challenged the Crown's title to the land. That defence was peremptorily dismissed. According to Stephen CJ 'the waste lands of this Colony are, and ever have been, from the time of first

28 D. V. Williams, A Simple Nullity? The Wi Parata Case in New Zealand Law and History (Auckland, 2011), 199-233. See also D. V. Williams, 'Historians' Context and Lawyers' Presentism: Debating Historiography or Agreeing to Differ', New Zealand Journal of History, 48(2) (2014), 136-60.

29 B. Kercher, 'Perish or Prosper: The Law and Convict Transportation in the British Empire, 1700-1850', Law and History Review, 21(3) (2003), 527-84.

30 Australian Courts Act 1828, 9 Geo IV c. 83, s. 24, came into force on 25 July 1828.

31 Attorney-General (NSW) v. Brown (1847) 1 Legge 312. 
settlement in 1788, in the Crown; that they are, and ever have been, from that date (in point of legal intendment), without office found, in the Sovereign's possession'. He went on to aver that 'At the moment of its settlement the colonists brought the common law of England with them.' Waste lands of the Crown was a term that 'meant all the waste and unoccupied lands of the colony; for, at any rate, there is no other proprietor'. Furthermore, even though the radical title of the Crown was a fiction in English law, in a newly-discovered country, settled by British subjects, the occupancy of the Crown with respect to the waste lands of that country, is no fiction. ... Here is a property, depending for its support on no feudal notions or principle. ${ }^{32}$

The invisibility and irrelevance of indigenous peoples in actual possession of large tracts of the continent within the boundaries of New South Wales could hardly be more striking to modern eyes, but the law laid down was abundantly clear. Similarly, the Privy Council in 1889 had no difficulty in identifying the law applicable to land rights in New South Wales. In Cooper v. Stuart, the self-same Lord Watson, who had delivered the Privy Council decision in St Catherine's the previous year, had this to say about New South Wales:

The extent to which English law is introduced into a British Colony, and the manner of its introduction, must necessarily vary according to circumstances. There is a great difference between the case of a Colony acquired by conquest or cession, in which there is an established system of law, and that of a Colony which consisted of a tract of territory practically unoccupied, without settled inhabitants or settled law, at the time when it was peacefully annexed to the British dominions. The Colony of New South Wales belongs to the latter class. ${ }^{33}$

In support of this proposition, Lord Watson quoted the famous passage from Blackstone's Commentaries, Book I, that I quoted above. He then addressed what the relevant land law might be:

There was no land law or tenure existing in the Colony at the time of its annexation to the Crown; and, in that condition of matters, the conclusion appears to their Lordships to be inevitable that, as soon as colonial land became the subject of settlement and commerce, all transactions in relation to it were governed by English law, in so far as that law could be justly and conveniently applied to them. ${ }^{34}$

32 Ibid., 316-18.

${ }^{33}$ Cooper v. Stuart [1889] 14 App Cas 286, [1889] UKPC 1 (henceforth, Cooper), para 11.

${ }^{34}$ Ibid., para 13. 
Even as late as 1971, in a test case seeking recognition of aboriginal title to land on the Gove Peninsula in the Northern Territory of Australia, Blackburn J in a lengthy judgment refused to shift from the orthodoxy of those precedents. He affirmed the view that 'the Crown is the source of title to all land', that all land is held mediately or immediately of the Crown and that on the foundation of New South Wales 'every square inch of territory in the colony became the property of the Crown'. ${ }^{35}$ The Gove Peninsula, incidentally, is some 2,889 kilometres from Sydney. There are a large number of square inches between the location where a small penal colony was established at Botany Bay and Port Jackson in 1788 and the territory of the Yolngu people, who have occupied the Gove region for at least 60,000 years. This seems a very long stretch for a doctrine that, so it was said, 'is no fiction'.

Moving some 2,155 kilometres from Sydney in a different direction across the Tasman Sea to New Zealand - legal history on the radical title of the Crown has followed a very different trajectory to that of either Canada or Australia. In Canada, there were multitudes of alliances, treaties and other legal transactions between indigenous peoples and the Crown in northern America prior to confederation pursuant to the British North America Act 1867. Then, post-confederation in western Canada, there were eleven 'numbered treaties' entered into between 1871 and 1921. All these treaties are important to the narratives on radical title and extinguishment of indigenous rights. In Australia, on the other hand, there were no authorised treaties at all between the Crown and the continent's prior inhabitants. There was an 1835 unratified document, often called Batman's Treaty, purporting to purchase a large tract of land from the Aboriginal people in the area that is now Melbourne. The story of that one and only Australian attempt to treat formally with the indigenous peoples prior to being dispossessed of their lands has been told well by Bain Attwood. ${ }^{36}$

In New Zealand, however, just one treaty signed at the outset of colonial rule in 1840 continues to define Maori-Crown relations. ${ }^{37}$ In New Zealand's flexible and evolving Westminster-style constitutional

35 Milirrpum v. Nabalco Pty Ltd (1971) 17 FLR 141, 245.

36 B. Attwood (assisted by H. Doyle), Possession: Batman's Treaty and the Matter of History (Carlton, 2009).

37 C. Orange, The Treaty of Waitangi (Wellington, 2011). Although, see R. Boast, 'Treaties Nobody Counted On', Victoria University of Wellington Law Review, 42(2) (2011), $653-70$. 
arrangements, the Treaty of Waitangi is described now in the Cabinet Manual 2017 as 'a founding document of government in New Zealand'. ${ }^{38}$ There have been disputes as to the congruence of the Maori text, signed by a large proportion of Maori tribal leaders throughout the New Zealand islands in 1840, with an English text of the treaty. Both texts, though, are embedded in the schedule to the Treaty of Waitangi Act 1975, which created the Waitangi Tribunal to inquire into and report on issues between Maori and the Crown.

There has been significant debate also about whether or not the Treaty's provisions align with whatever protection a colonial court may have provided under what is now known as the Common law doctrine of aboriginal title. ${ }^{39}$ In my view, Ned Fletcher is right to argue that policies based on the Treaty initially guaranteed a good deal more protection to Maori interests than any American or colonial common-law court would have permitted:

The principal conclusions of the thesis are that British intervention in New Zealand in 1840 was to establish government over British settlers, for the protection of Maori. British settlement was to be promoted only to the extent that Maori protection was not compromised. Maori tribal government and custom were to be maintained. British sovereignty was not seen as inconsistent with plurality in government and law. Maori were recognised as full owners of their lands, whether or not occupied by them, according to custom. ${ }^{40}$

That high level of protection for Maori interests, and the broad recognition of Maori property rights in all land, was anathema to the New Zealand Company - a private company seeking to bring settlers to New Zealand. The Company had friends in high places in Westminster. In 1844, a House of Commons select committee resolved that the conclusion of the Treaty of Waitangi 'was a part of a series of injudicious proceedings' and the recognition of Maori property in 'wild

${ }^{38}$ K. Keith, 'On the Constitution of New Zealand: An Introduction to the Foundations of the Current Form of Government', in Cabinet Manual 2017 (Wellington, 2017), 1.

39 M. Hickford, Lords of the Land: Indigenous Property Rights and the Jurisprudence of Empire (Oxford, 2011).

${ }^{40}$ N. Fletcher, 'A Praiseworthy Device for Amusing and Pacifying Savages? What the Framers Meant by the English Text of the Treaty of Waitangi', unpublished $\mathrm{PhD}$ thesis University of Auckland (2014), iii-iv. 
lands' was 'an error which has been productive of very injurious consequences'. ${ }^{41}$ In support of their view that native title rights should be narrowed as much as possible so as to enable rapid emigration of settlers to the new colony, Company advocates - including Henry Chapman, the proprietor-editor of the New Zealand Journal (a newspaper subsidised by the Company) - called in aid the jurisprudence of Marshall CJ in a famous trilogy of cases from 1823 to 1832 on federal Indian law ${ }^{42}$ and in Kent's Commentaries. ${ }^{43}$ Company supporters argued for a 'fundamental principle of colonial law' that native rights should be admitted only when based on actual current occupation of small areas of land. ${ }^{44}$ Opposing that view, and defending his Tory government's much more generous interpretation of the Treaty of Waitangi, a member of the Commons in 1845 declaimed:

I suspect I know the origin of this new fundamental principle of colonial law. It comes, I think, from the land in which the Black Man is a slave, and the Red Men of the forest are driven and hunted from their lands, as the Seminole and other Indians have been, according to certain adjudications that Indians have no property to the soil of their respective territories than that of mere occupancy. ${ }^{45}$

Not long after that debate, however, the Tory government lost a vote of no confidence and a new Whig ministry replaced it. Viscount Howick, who had chaired the 1844 select committee in the Commons, but was now the third Earl Grey, sitting in the Lords, became the Secretary of State for War and the Colonies in the Whig administration. ${ }^{46}$ With that

41 'Report from the Select Committee on New Zealand together with the Minutes of Evidence, Appendix, and Index', British Parliamentary Papers, Colonies New Zealand, vol. II (Dublin, 1968), v-vi, xii (2d Resolution).

42 Johnson v. M'Intosh (1823) 21 US 543; Cherokee Nation v. State of Georgia (1831) 30 US 1; Worcester v. State of Georgia (1832) 31 US 515.

43 J. Kent, Commentaries on American Law, 3rd edn (New York, 1836), vol. III, part VI, lecture LI [51].

${ }^{44}$ H. S. Chapman, The New Zealand Portfolio: Embracing a Series of Papers on Subjects of Importance to the Colonists (London, 1843).

${ }^{45}$ M. Hickford, "Decidedly the Most Interesting Savages on the Globe": An Approach to the Intellectual History of Maori Property Rights, 1837-53', History of Political Thought 27(1) (2006), 122-67, citing at 159 'A Corrected Report of the Debate in the House of Commons on the 17th, 18th, and 19th of June 1845 on the State of New Zealand and the Case of the New Zealand Company (London, 18 June 1845), 124'.

46 P. Burroughs, 'Grey, Henry George, Third Earl Grey (1802-1894)', in Oxford Dictionary of National Biography (Oxford, 2004), available at www.oxforddnb.com/view/10.1093/ref: odnb/9780198614128.001.0001/odnb-9780198614128-e-11540?rskey=5Y3XwE\&result=4. 
change of government in the United Kingdom, and also a change of governor in the colony, by 1847 the scene was set to bring a test case in the New Zealand Supreme Court. The new governor issued a Crown grant over land to one of his own officials who had no personal nor pecuniary interest in that land. This collusive piece of litigation was designed to obtain findings from the Supreme Court to reaffirm Crown pre-emption in dealing with Maori land (waived for a period by the previous governor). The governor sought rulings that the radical title to all land was vested in the Crown and only by Crown grants could settlers obtain a lawful title to land. In reaching this conclusion the Court was not called on to inquire exactly how (and with what justice) Maori customary interests had been extinguished prior to the Crown grant.

By now, Henry Chapman was a judge on the New Zealand Supreme Court bench. In the case concerning this grant, $R$ v. Symonds, he and Martin CJ duly cited and relied upon the Marshall CJ decisions. Those American precedents, they held, laid down the settled law applicable in colonies such as New Zealand. The Treaty of Waitangi was now realigned to conform to them. According to Chapman J, in 'solemnly guaranteeing the Native title' and 'the Queen's pre-emptive right', the Treaty of Waitangi 'does not assert either in doctrine or in practice any thing new and unsettled'. ${ }^{47}$ The reasoning in Symonds relied heavily on Johnson v. M'Intosh and quoted with approval Kent's summary of the decision that 'on the discovery of this continent by the nations of Europe, the discovery was considered to have given to the government by whose subjects or authority it was made, a title to the country, and the sole right of acquiring the soil from the natives'. ${ }^{48}$ It should be noted, too, that Chapman J did not apply to New Zealand Marshall CJ's later recognition in Cherokee v. Georgia that the indigenous communities in that state should be recognised as being 'domestic dependent nations'. ${ }^{49}$

${ }^{47} R$ v. Symonds (1847) NZPCC 387, 388-90; [1847] NZHC 1 (henceforth, Symonds).

${ }^{48}$ Ibid. For critiques of the assumptions of 'discovery' by Europeans underlying aboriginal title law, see R. A. Williams, Jr, Like a Loaded Weapon: The Rehnquist Court, Indian Rights, and the Legal History of Racism in America (Minneapolis, MN, 2005); R. A. Williams, Jr, The American Indian in Western Legal Thought: The Discourses of Conquest (New York, 1990); S. J. Anaya, Indigenous Peoples in International Law, 2nd edn (New York, 2004); R. J. Miller, Native America, Discovered and Conquered: Thomas Jefferson, Lewis and Clark, and Manifest Destiny (Lincoln, NE, 2008).

49 A more accurate analysis, in my opinion, than that by Chapman J of the Marshall decisions and Kent's Commentaries is to be found in the 'infamous' judgment in Wi Parata v. Bishop of Wellington (1877) 3 NZJR (NS) SC 72 (henceforth, Parata). See Williams, A Simple Nullity?, 167-73, 225-6. 
Colonial government policy in New Zealand, following Symonds, ruled out the possibility that Maori customary law would govern land transactions between Maori and Europeans. It was local statute law - not American law nor Common law nor iure gentium - that assessed the validity of land transactions, known as 'old land claims', entered into prior to 1840. A Land Claims Act 1840 was passed by the legislature of New South Wales (when New Zealand was a dependency of that colony) and was reenacted as the Land Claims Ordinance 1841 after New Zealand was erected as a separate colony. ${ }^{50}$ This legislation assessed old land claims not by reference to Maori customary law, nor by assessing the intentions of Maori in entering into pre-Treaty land transactions, but rather by the amount paid to Maori in any purported purchase. A schedule to these statutes sets out a scale: 6 pence per acre would suffice to justify any transactions prior to the end of 1824; 8 pence per acre from 1824 to 1829 ; and so on, rising to between 4 and 8 shillings per acre in $1839 .{ }^{51}$ In all cases, however, the commissioners appointed to inquire into old land claims could not make an award in excess of 2,560 acres. One who refused to accept this law was James Busby, who had served as British Resident from 1835 until the Treaty of Waitangi. He challenged the validity of the Land Claims Ordinance 1841, which treated his pre-Treaty of Waitangi land purchases as 'null and void'. For two decades he continued to maintain his claim to hold large areas of land under 'native title' as conferred on him by Maori. All his efforts came to nought in $1859 .{ }^{52}$ Then, from 1862 , the Native Land Court became the instrument for extinguishing customary title. Under its statute-bestowed jurisdiction, this court devised its own understandings of Maori customs and usages so as to extinguish them as rapidly as possible, and thus free up Maori land for the government to make it available for incoming settlers. ${ }^{53}$

Hence it was statute law - not the Common law and not the Treaty of Waitangi - that determined and governed Maori-Crown relationships.

${ }^{50}$ New Zealand Land Claims Act 1840 (NSW) 4 Vict No 7; Land Claims Ordinance 1841 (NZ) 4 Vict No 2.

${ }^{51}$ Schedule D of the 1840 Act; Schedule B of the 1841 Ordinance.

52 B. Fletcher and S. Elias, 'A Collusive Suit to "Confound the Rights of Property Through the Length and Breadth of the Colony"?: Busby v White (1859)', Victoria University of Wellington Law Review, 41 (2010), 563-604.

${ }^{53}$ R. Boast, Buying the Land, Selling the Land: Governments and Maori Land in the North Island 1865-1921 (Wellington, 2008); D. V. Williams, 'Te Kooti tango whenua': The Native Land Court 1864-1909 (Wellington, 1999). 
The statutory definition of 'customary land' was 'land vested in the Crown and held by Natives under the customs and usages of the Maori people. ${ }^{54}$ An explanatory memorandum for the Bill that became the Native Land Act 1909 explained the crucial role of Crown radical title, as understood in New Zealand law, in explicitly denying court enforceable rights to Maori (until Ngati Apa in 2003):

Customary land, since it has never been Crown-granted, belongs to the Crown. It is in a wide sense of the term Crown land, subject, however, to the right of those Natives who by virtue of Maori custom have a claim to it to obtain a Crown grant (or a certificate of title under the Land Transfer Act in lieu of a grant) on the ascertainment of their customary titles by the Native Land Court. This right of the Natives to their customary lands was recognised by the Treaty of Waitangi in 1840 . In its origin it was merely a moral claim, dependent on the good will of the Crown, and not recognisable or enforceable at law. ${ }^{55}$

And yet there is a significant body of scholarship that has looked to legal history in order to bolster the claims of the modern Common law doctrine of aboriginal title as a coherent corpus of jurisprudence applicable to Canada, Australia and New Zealand alike where indigenous rights are enforceable in the ordinary courts and the source of those rights lie (or should lie) in indigenous law conceptions. This has been described by Mark Hickford as 'a golden thread of reasoning about native title independently actionable at Common law in the courts. ${ }^{56}$ Three Privy Council cases in particular are regularly cited in support of these claims: Nireaha Tamaki v Baker (1901) $;{ }^{57}$ In re Southern Rhodesia $(1919) ;{ }^{58}$ and

54 Native Land Act 1909, s. 2. This remained the law in force until the passage of Te Ture Whenua Maori Act/Maori Land Act 1993, s. 129(2)(a): 'Land that is held by Maori in accordance with tikanga Maori [Maori custom law] shall have the status of Maori customary land.' This then relatively recent statutory amendment was in force by the time the Ngati Apa decision was delivered in 2003.

55 J. W. Salmond, 'Native Land Bill: Memorandum. Notes on the History of Native-Land Legislation', Number 87-3, Bill Books, 1909, 1, Parliamentary Counsel Office, Wellington; H. Bassett, R. Steel and D. V. Williams, Mãori Land Legislation Manual (Wellington, 1994), Appendix C, 95.

${ }^{56}$ M. Hickford, 'John Salmond and Native Title in New Zealand: Developing a Crown Theory on the Treaty of Waitangi, 1910-1920', Victoria University of Wellington Law Review, 38 (2007), 853-924, at 873.

57 [1901] AC 561; [1901] UKPC 18 (on appeal from the New Zealand Court of Appeal) (henceforth, Tamaki).

58 [1919] AC 211 (a matter specially referred to the Judicial Committee by an Order in Council under the Judicial Committee Act 1833, s. 4, for hearing and consideration) (henceforth, Southern Rhodesia). 
Amodu Tijani $v$ Secretary, Southern Nigeria (1921). ${ }^{59}$ The Canadian scholar Kent McNeil cites all three cases for the proposition that they 'make clear that Indigenous laws, when revealed by evidence, can give rise to legal land rights enforceable in common law courts'. ${ }^{60}$ The Australian scholar Ulla Secher cites all three cases for a proposition 'contrary to the conventional view' that 'the Crown does not have a present proprietary interest underlying Aboriginal title' and furthermore that St Catherine's is not authority for the view 'that the Crown's radical title is necessarily a full proprietary estate underlying any pre-existing title which is recognised by the common law'. ${ }^{61}$ Whilst respecting the passion of these authors to advance indigenous peoples' rights, I submit that the facts of each case, the actual outcome following each decision, and the surrounding historical context of each case point to untidiness, ambiguity and a distinct lack of coherence in the Common law. Edward Cavanagh, on the other hand, is closer to historical veracity when he suggests that 'the jurisprudence of the highest imperial court of appeal at the time' led to decisions that 'often hung on the ad hoc response ... to a particular colonial political crisis. In this court, history and precedent alike never served, but were instead made subservient to a pragmatic ambition to bolster the constitution of the Empire Commonwealth. ${ }^{36}$

The Tamaki litigation in New Zealand began with a number of orders of the Native Land Court in 1871 individualising the customary title of members of the Rangitane tribe. ${ }^{63}$ Much of the land was immediately sold to the Crown and was proclaimed Crown land, but survey requirements of the Native Land Acts were not fully complied with. In 1893 the Crown offered the sold lands for on-sale to European settlers. Nireaha Tamaki, and other non-sellers awarded title in an adjacent block, then seized on the surveying irregularity to claim that their customary title had not in fact been extinguished by the 1871 court orders. Richmond J delivered the brief judgment of the Court of Appeal in 1894:

[1921] 2 AC 399; [1921] UKPC 80 (on appeal from the Supreme Court of Nigeria) (henceforth, Tijani).

${ }^{60}$ McNeil, Flawed Precedent, 124.

${ }^{61}$ U. Secher, Aboriginal Customary Law: A Source of Common Law Title to Land (Oxford, 2014), 75-6. The foreword to this book is by Kent McNeil, vii-viii.

${ }^{62}$ E. Cavanagh, 'Colonial History and the Language of the Judiciary: Aboriginal Rights Before and After Tsilhqot'in', unpublished paper, Department of Justice, Ottawa, 10 February 2014, 8.

63 Waitangi Tribunal, The Wairarapa ki Tararua Report, Wai 863, vol. II (Wellington, 2010), 395-554, esp. 466-70. 
The plaintiff comes here on a pure Maori title, and the case is within the direct authority of Wi Parata v. The Bishop of Wellington. We see no reason to doubt the soundness of that decision. ... There can be no known rule of law by which the validity of dealings in the name and under the authority of the Sovereign with the Native tribes of this country for the extinction of their territorial rights can be tested. Such transactions began with the settlement of these Islands; so that Native custom is inapplicable to them. The Crown is under a solemn engagement to observe strict justice in the matter, but of necessity it must be left to the conscience of the Crown to determine what is justice. The security of all titles in the country depends on the maintenance of this principle. ${ }^{64}$

An appeal was eventually heard by the Privy Council in 1901. The Judicial Committee humbly advised His Majesty that the appeal should be allowed. After quoting in full the English text of the Treaty of Waitangi and many statutes beginning with the Land Claims Ordinance 1841, Lord Davey was of the opinion that if the appellant can succeed in proving that he and the members of his tribe are in possession and occupation of the lands in dispute under a native title which has not been lawfully extinguished, he can maintain this action to restrain an unauthorised invasion of his title'. ${ }^{65}$ Too much weight has been accorded by adherents of 'a golden thread of reasoning' to this successful appeal by a Maori plaintiff to the Privy Council. The actual outcome of the case was a settlement payment to Tamaki of $£ 4,566$ minus court costs and his agreement to the extinguishment by legislation of native title to the disputed land. ${ }^{66}$

As to the 1877 Parata precedent, their Lordships opined that dicta in that case, especially in relation to the interpretation of the Native Rights Act 1865, 'went beyond what was necessary for the decision' and were plainly wrong. Native title was indeed cognisable and had been recognised in statutes. Nevertheless, their Lordships saw 'no reason to doubt

${ }^{64}$ Nireaha Tamaki v. Baker (1894) 12 NZLR 483, 488.

${ }^{65}$ Nireaha Tamaki v. Baker [1901] AC 561 (henceforth, Tamaki (PC)), 578.

${ }^{66}$ Native Land Claims Adjustment and Laws Amendment Act 1901, s. 27; Waitangi Tribunal, The Wairarapa ki Tararua Report, 401. Relatives of Tamaki still wished to pursue the case in court: Nireaha Tamaki v. Baker (1902) 22 NZLR 97. Their action was discontinued by the Maori Land Claims Adjustment and Laws Amendment Act 1904, s. 4. More generally, a ten-year limitation period was imposed on any litigation designed to question findings of the Native Land Court: Land Titles Protection Act 1902. The Native Land Act 1909, ss. 84-87, codified the Parata precedent in stipulating that any claims by Maori that their customary title rights had not been properly extinguished prior to the issue of a Crown grant or a Native Land Court order were non-justiciable in the ordinary courts. 
the correctness of the conclusion arrived at' by Richmond $\mathrm{J}$ and Prendergast $\mathrm{CJ}$ in refusing to annul a Crown grant that implied native title had been extinguished. ${ }^{67}$ The colonial judiciary in a number of subsequent cases applied the Parata precedent so that customary title could not be enforced in the ordinary courts. ${ }^{68}$ Maori would have their rights recognised in court but if, and only if, they could point to a statutory basis for their claims. ${ }^{69}$

Secher's criticisms of Parata, and of decisions that followed it, are in some respects seriously misconceived. For a start, she misunderstands a quotation from the Parata judgment as being a statement that New Zealand was acquired as a colony by cession. ${ }^{70}$ On the contrary, the judges concluded that Maori were 'primitive barbarians' who lacked the capacity to enter into a treaty so that the Treaty of Waitangi was 'a simple nullity. ${ }^{71}$ Secondly, she asserts that there was a 'marked contrast' between the Symonds reasoning and that in Parata. ${ }^{72}$ I would argue that, in all essential aspects of the actual decisions, Symonds and Parata are closely aligned, including, as expressed in Parata, that there is a duty on the sovereign 'as supreme protector of aborigines, of securing them against any infringements of their right of occupancy. ${ }^{73}$ Thirdly, Secher states that the Privy Council in Tamaki 'effectively overruled the decision' in Parata. ${ }^{74}$ As noted above, the Privy Council did not doubt the correctness of the Parata decision, and it was followed on numerous occasions after $1901 .^{75}$

It is likewise odd that the Southern Rhodesia case is invoked in support of a court enforceable doctrine of Common law aboriginal title rights. ${ }^{76}$ In that case, legal arguments submitted by the Anti-Slavery and Aborigines' Protection Society asked the Judicial Committee to uphold the land rights of the native population rather than focus on the dispute between the British South Africa Company and the settlers' Legislative

67 Tamaki (PC), 579.

${ }^{68}$ Hohepa Wi Neera $v$ Bishop of Wellington (1902) 21 NZLR 655.

69 Tamihana Korokai v Solicitor-General (1912) 32 NZLR 321; Te Heuheu Tukino v. Aotea District Maori Land Board [1941] AC 308, [1941] UKPC 6.

${ }^{70}$ Secher, Aboriginal Customary Law, 69.

${ }^{71}$ Parata, 77-78.

72 Secher, Aboriginal Customary Law, 70.

73 Williams, A Simple Nullity?, 170-2.

74 Secher, Aboriginal Customary Law, 75.

75 The Parata precedent was cited with approval by the New Zealand Court of Appeal as late as 1963: In re the Ninety-Mile Beach [1963] NZLR 461, 475.

76 Secher, Aboriginal Customary Law, 446. 
Council concerning 'unalienated lands' ${ }^{77}$ In his rejection of these submissions, Lord Sumner pronounced:

The estimation of the rights of aboriginal tribes is always inherently difficult. Some tribes are so low in the scale of social organization that their usages and conceptions of rights and duties are not to be reconciled with the institutions or the legal ideas of civilized society. Such a gulf cannot be bridged. It would be idle to impute to such people some shadow of the rights known to our law and then to transmute it into the substance of transferable rights of property as we know them. In the present case it would make each and every person by a fictional inheritance a landed proprietor 'richer than all his tribe.' On the other hand, there are indigenous peoples whose legal conceptions, though differently developed, are hardly less precise than our own. When once they have been studied and understood they are no less enforceable than rights arising under English law. Between the two there is a wide tract of much ethnological interest, but the position of the natives of Southern Rhodesia within it is very uncertain; clearly they approximate rather to the lower than to the higher limit. ...

Whoever now owns the unalienated lands, the natives do not. ${ }^{78}$

The crucial historical context for this decision was the pragmatic consideration that Southern Rhodesia was destined in the minds of Britain's rulers to be a territory dominated by European settlers and any extensive recognition of native title rights would be most inconvenient.

Southern Nigeria provided a very different historical context. This was a region where there was a large African population and a very high death rate for European residents from 'blackwater fever' (malaria) and other diseases. Tropical Africa did not attract European settlers who might one day claim the right to responsible self-government as was envisaged in Rhodesia. A tiny number of European colonial officials were called on to exercise political domination in tropical Africa colonies. The solution they arrived at to deal with what Mahmood Mamdani names as the 'native problem' in such colonies and protectorates was to institute a

77 E. Cavanagh, 'The Unbridgeable Gulf: Responsible Self-Government and Aboriginal Title in Southern Rhodesia and the Commonwealth', in S. Dubow and R. Drayton (eds.), Commonwealth History in the Twenty-First Century (Cham, 2020), 81-99; see also E. Cavanagh, 'Crown, Conquest, Concession, and Corporation: British Legal Ideas and Institutions in Matabeleland and Southern Rhodesia, 1889-1919', in E. Cavanagh (ed.), Empire and Legal Thought: Ideas and Institutions from Antiquity to Modernity (Leiden, 2020).

78 Southern Rhodesia, 233-5. 
system of administration known as indirect rule. ${ }^{79}$ The leading proponent of indirect rule was Sir Frederick Lugard (later Baron Lugard of Abinger), who spent a good deal of his career in Nigeria and later wrote up his ideas in The Dual Mandate in British Tropical Africa. ${ }^{80}$ Under this policy, external, military and tax control was operated by the British, while most aspects of life were left to local traditional chiefs and their courts.

One such chief in 1921 was Amodu Tijani, Chief Oluwa of Lagos. He most certainly did win a case appealed to the Privy Council. It held that he was entitled to full compensation for land taken for public purposes on the footing that he had exercised full ownership rights in the land. In reaching that result, Viscount Haldane LC made an observation that was cited with warm approval in Mabo (No. 2) and Ngati Apa:

There is a tendency, operating at times unconsciously, to render [native] title conceptually in terms which are appropriate only to systems which have grown up under English law. But this tendency has to be held in check closely. As a rule, in the various systems of native jurisprudence throughout the Empire, there is no such full division between property and possession as English lawyers are familiar with....

To ascertain how far this latter development of right has progressed involves the study of the history of the particular community and its usages in each case. Abstract principles fashioned a priori are of but little assistance, and are as often as not misleading.

In the case of Lagos and the territory round it, the necessity of adopting this method of inquiry is evident. As the result of cession to the British Crown by former potentates, the radical title is now in the British Sovereign. But that title is throughout qualified by the usufructuary rights of communities, rights which, as the outcome of deliberate policy, have been respected and recognised. ${ }^{81}$

That the Tijani case is now considered so authoritative ought not to lead one to the conclusion that there was a coherent body of Common law to be found in Privy Council case law. On the contrary, as their Lordships themselves stressed, 'abstract principles' should be avoided in favour of inquiring into 'the history of the particular community'. The Privy Council was willing to assess for itself (without much or any evidence, and on a case by case basis) whether indigenous peoples held legal

79 M. Mamdani, Citizen and Subject: Contemporary Africa and the Legacy of Late Colonialism (Princeton, 2018).

${ }^{80}$ F. D. Lugard, The Dual Mandate in British Tropical Africa (Edinburgh, 1922).

81 Tijani, 403-4. 
conceptions that were 'hardly less precise' than English property law concepts, or if they were on lower rungs in the scales of civilisation.

I conclude, therefore, as I suggested at the outset, that coherence and clarity cannot be found in a legal history of the doctrine of aboriginal title. Radical title seems to be a creature akin to a chimera, composed of a variety of disparate parts. In Privy Council cases such as St Catherine's, Cooper, Tamaki, Southern Rhodesia and Tijani, it was policy and pragmatism deemed appropriate for the time, place and historical context of each case that tended to triumph, rather than principled Common law reasoning. 